\title{
Development of a fast and reliable diagnostic method for American foulbrood disease (Paenibacillus larvae subsp. larvae) using a 16S rRNA gene based PCR
}

\author{
Wim DobBelaerE ${ }^{\mathrm{a}, \mathrm{b} *}$, Dirk C. DE GRAAF ${ }^{\mathrm{a}}$, Johan E. PeETERS ${ }^{\mathrm{a}}$, \\ Frans J. JACOBS ${ }^{\mathrm{b}}$ \\ a Veterinary and Agrochemical Research centre, Groeselenberg 99, 1180 Brussels, Belgium \\ b University of Ghent, Laboratory of Zoophysiology, Krijgslaan 281 S33, \\ 9000 Ghent, Belgium
}

(Received 18 January 2001; revised 9 April 2001; accepted 1 May 2001)

\begin{abstract}
Paenibacillus larvae larvae is the causative agent of American foulbrood (AFB), a serious honeybee disease. The ability to detect and identify this organism promptly is important to allow effective sanitary measures in case of AFB. P. larvae larvae is a fastidious and slow-growing bacterium and primary isolation and presumptive identification can be difficult and time-consuming. In this study the use of PCR is described for a rapid and reliable diagnosis. The developed PCR assay is specific for $P$. larvae as no amplicons were produced from 13 related or hive-related species. Only with $P$. larvae larvae and $P$. larvae pulvifaciens DNA as template, an amplicon was formed. A positive reaction was also observed when DNA was extracted directly from remains of an AFB diseased larva. Thus this PCR assay provides a reliable diagnosis for AFB in only 4 hours.
\end{abstract}

American foulbrood / diagnosis / Paenibacillus larvae larvae / PCR / 16S rRNA

\section{INTRODUCTION}

American foulbrood (AFB) caused by Paenibacillus larvae subsp. larvae (formerly Bacillus larvae) (Heyndrickx et al., 1996) is a primary disease of honeybees (Ratnieks et al., 1995). AFB will almost always kill the larvae after they have spun their cocoons. The cappings over such larvae quickly become moist and darkcoloured, they then sink inwards. When a matchstick is thrust into the larval remains at the sunken capping stage and then removed, it draws out the brown, viscous remains in a ropy thread

* Correspondence and reprints

E-mail: widob@var.fgov.be 
(Bailey and Ball, 1991). Laboratory diagnosis of the disease is in most cases based on analysis of these symptoms followed by the isolation and identification of the pathogen. According to the manual of the Office International des Epizooties, this can be done, by a simple milk curding test (Bailey and Ball, 1991), but this test is not always conclusive. Hornitzky and Wilson (1989) reported on the examination of smears as a fast and easy method for the diagnosis of both AFB and European foulbrood (EFB). Another possibility is the use of biochemical identification kits, such as API 50CHB (Carpana et al., 1995) or BBL Crystal (Dobbelaere et al., 2001). Although they also offer a reliable diagnosis, the slow growth rate of the bacteria and the presence of numerous other microbiological organisms in the hive (Gilliam, 1997) and in the honey (Snowdon and Cliver, 1996) hampers such an approach. A faster and more reliable diagnosis is therefore needed.

Nucleic acid amplification of a specific target region of the bacterial genome by the polymerase chain reaction (PCR) is becoming widely used for detection and diagnostic purposes (Whelen and Persing, 1996; Vaneechoutte and VanEldere, 1997). The ability to amplify DNA specifically by PCR from low numbers of bacteria, as well as its simplicity, rapidity and reproducibility, offer advantages over the conventional cultural and phenotypic methods for identification. In a previous study, Govan et al. (1999) described the use of PCR for rapid identification of $P$. larvae. It was shown that the used primers, located in the $16 \mathrm{~S}$ rRNA region, generated an amplicon specific to the tested reference strain of $P$. larvae larvae. However, as there are no clinical cases of AFB in South-Africa (Govan et al., 1999) the method was not tested on more than one strain of $P$. larvae larvae nor any infected larvae. Furthermore, only 4 related species (i.e. P. alvei, $P$. polymyxa, B. pumilus and $B$. subtilis) were tested for possible crossreactions with the given primers.
The aim of this study was to search for more possible primers, in addition to the ones reported before (Govan et al., 1999), to test for possible cross-reactions with more related species and to develop, based on PCR with these primers, a rapid and reliable diagnosis of AFB, starting directly from remains of diseased larvae.

\section{MATERIALS AND METHODS}

\subsection{Cultures and brood samples}

The origin of the 175 strains of P. larvae larvae used in this study is threefold. 5 strains are reference strains from the LMG-collection (Laboratory of Microbiology Ghent, University of Ghent, Belgium) i.e. LMG 9820, LMG 14425, LMG 14426, LMG 15969 and LMG 16245. 146 strains are isolated in a screening of 1328 Belgian honey samples and 24 strains are isolated from diseased brood from different cases of AFB in Belgium from 1995 till now.

The 141 brood samples, used in this study were collected throughout 1998 and 1999 in apiaries from different parts of the country and stored at $-20^{\circ} \mathrm{C}$ till used. The honey sample used was collected in the screening mentioned above.

\subsection{Design of the primers}

The 16S rRNA sequence of $P$. larvae larvae (Genbank accession No. X60619) together with 3 partial sequences of the same gene (Genbank accession No. U85263, U86605 and U86606; http://www.ncbi.nlm. nih.gov/Genbank/) were aligned with homologous sequences of 16 related Bacillus and Paenibacillus species, using the Vector NTI program (Informax, Inc.). The list of the used species and sequences is represented in Table I. Based on this alignment we chose a set of primers that were specific for $P$. larvae larvae. 
Table I. List of the 16S rRNA sequences used for alignment with the $16 \mathrm{~S}$ rRNA sequence of $P$. larvae larvae.

\begin{tabular}{lclc}
\hline Species & $\begin{array}{c}\text { Genbank } \\
\text { accession No. }\end{array}$ & Species & $\begin{array}{c}\text { Genbank } \\
\text { accession No. }\end{array}$ \\
\hline P. larvae pulvifaciens & $\mathrm{X} 60636$ & Bacillus cereus & $\mathrm{Z} 84575$ \\
P. alvei & $\mathrm{D} 78317$ & & $\mathrm{Z} 84578$ \\
& $\mathrm{X} 57304$ & & $\mathrm{Z} 84579$ \\
P. apiarius & $\mathrm{X} 60604$ & & $\mathrm{Z} 84581$ \\
P. lautus & $\mathrm{U} 49247$ & & $\mathrm{Z} 84589$ \\
& $\mathrm{D} 78472$ & & $\mathrm{Z} 84590$ \\
& $\mathrm{D} 78473$ & B. licheniformis & $\mathrm{D} 31739$ \\
& $\mathrm{D} 85609$ & & $\mathrm{X} 60623$ \\
P. lentimorbus & $\mathrm{D} 85394$ & & $\mathrm{X} 68416$ \\
& $\mathrm{X} 60622$ & B. megaterium & $\mathrm{D} 16273$ \\
P. pabuli & $\mathrm{AF} 071861$ & & $\mathrm{X} 60629$ \\
P. gordonae & $\mathrm{X} 60630$ & B. pumilus & $\mathrm{X} 60637$ \\
P. validus & $\mathrm{X} 60617$ & & $\mathrm{AB} 020208$ \\
P. polymyxa & $\mathrm{D} 78320$ & B. subtilis & $\mathrm{X} 60646$ \\
& $\mathrm{X} 57308$ & & $\mathrm{AF} 058766$ \\
& $\mathrm{X} 60632$ & & $\mathrm{AF} 058767$ \\
& $\mathrm{D} 16276$ & B. thuringiensis & $\mathrm{Z} 84584$ \\
& $\mathrm{AJ} 223988$ & & $\mathrm{Z} 84585$ \\
P. popilliae & $\mathrm{AJ} 223989 \mathrm{Z}$ & & $\mathrm{Z} 8586587$ \\
& $\mathrm{X} 60633$ & & $\mathrm{Z} 84588$ \\
& $\mathrm{AF} 071859$ & & $\mathrm{Z} 84593$ \\
& $\mathrm{AF} 071860$ & & $\mathrm{Z} 84594$ \\
& & $\mathrm{Y} 18473$ \\
& & &
\end{tabular}

\subsection{Isolation of DNA}

We isolated DNA from the different strains in 2 different ways. Firstly the Puregene ${ }^{\circledR}$, Genomic DNA isolation kit for Gram-positive bacteria (Gentra systems) was used according to the manufacturers instructions. Secondly we simply heated a suspension of bacteria in $50 \mu \mathrm{l} \mathrm{H} \mathrm{O}$ for $15 \mathrm{~min}$ at $95^{\circ} \mathrm{C}$. After centrifugation for 5 minutes at $5000 \mathrm{rpm}$, the supernatant was used as DNA template in PCR reactions (Govan et al., 1999).

\subsection{PCR}

The reaction mixture $(50 \mu \mathrm{l})$ contained $10 \mu \mathrm{l}$ Q-solution (Qiagen), $5 \mu \mathrm{l}$ PCR buffer (providing $1.5 \mathrm{mM} \mathrm{MgCl}_{2}$ ) (Qiagen), $1.25 \mathrm{U}$ HotStarTaq polymerase (Qiagen), $50 \mathrm{pmol}$ of both forward and reverse primer, $200 \mu \mathrm{M}$ of each dNTP (Gibco BRL) and $1 \mu \mathrm{l}$ of template DNA preparation. Amplification was done in a thermocycler (Perkin Elmer GeneAmp PCR system 9600) and consisted of an initial activation of the HotStarTaq polymerase at $95{ }^{\circ} \mathrm{C}$ for $15 \mathrm{~min}$, followed by 30 cycles of: denaturation at $93{ }^{\circ} \mathrm{C}$ for $1 \mathrm{~min}$; annealing at $55^{\circ} \mathrm{C}$ for $30 \mathrm{~s}$; extension at $72{ }^{\circ} \mathrm{C}$ for $1 \mathrm{~min}$; ending with a final extension at $72{ }^{\circ} \mathrm{C}$ for $5 \mathrm{~min}$. Samples $(10 \mu \mathrm{l})$ of amplified products were electrophoresed in $0.8 \%$ agarose Type II (Sigma) in Tris-borateEDTA buffer containing ethidium bromide $\left(0.5 \mu \mathrm{g} \cdot \mathrm{ml}^{-1}\right)$ and the amplimers were visualized on a UV transilluminator and 
Table II. List of the 4 primers used in the study, and the theoretical length of the amplicons obtained with the four different combinations of the primers.

\section{Primer 1}

Primer 2

Primer 3 (Govan et al., 1999)

Primer 4 (Govan et al., 1999)

Combination 1-2

Combination 1-4

Combination 3-2

Combination 3-4 (Govan et al., 1999)

\section{5'CTTGTGTTTCTTTCGGGAGACGCCA3' \\ 5' TCTTAGAGTGCCCACCTCTGCG3' \\ 5' AAGTCGAGCGGACCTTGTGTTTC3' \\ 5' TCTATCTCAAAACCGGTCAGAGG3'}

Length of amplicon: $1106 \mathrm{bp}$

Length of amplicon: $970 \mathrm{bp}$

Length of amplicon: $1119 \mathrm{bp}$

Length of amplicon: $983 \mathrm{bp}$ photographed using the Kodak Digital science $^{\mathrm{TM}}$ Electrophoresis Documentation and Analysis System 120.

\subsection{Direct sampling of diseased brood}

Remains of 2 honeybee larvae were suspended in $1 \mathrm{ml}$ of sterile distilled $\mathrm{H}_{2} \mathrm{O}$ and mixed thoroughly. $100 \mu \mathrm{l}$ of this suspension was diluted in $900 \mu \mathrm{l}$ sterile distilled $\mathrm{H}_{2} \mathrm{O}$. This dilution was vortexed and $100 \mu \mathrm{l}$ of it was used to extract DNA by the heating and centrifugation method.

\section{RESULTS}

After the alignment of the sequences (Tab. I), 2 DNA sequences were found to be specific for $P$. larvae larvae and were retained for application as primers in a PCR reaction. These primers, and the ones described by Govan et al. (1999) are listed in Table II, together with the theoretical length of the amplicons. With a $P$. larvae larvae strain all 4 primer combinations generated amplicons with the expected length (Fig. 1).

14 different species (Tab. III) were tested for cross-reactions. All the tested species were closely related to P. larvae larvae and/ or were described to occur in beehives. Cross-reaction was only found with the P. larvae pulvifaciens strain, resulting in amplicons of the same length as with
P. larvae larvae strains for all 4 primer combinations. No other strain generated any amplicon with the 4 tested primer combinations under the specified PCR conditions.

As all primer combinations showed to be equally specific, all further tests were done with only 1 primer combination (i.e. primers 3 and 4). Till now 175 different strains of $P$. larvae larvae have been tested under these PCR conditions and each of them gave the expected amplicon. These tests were done based on DNA-extraction of a bacterial colony.

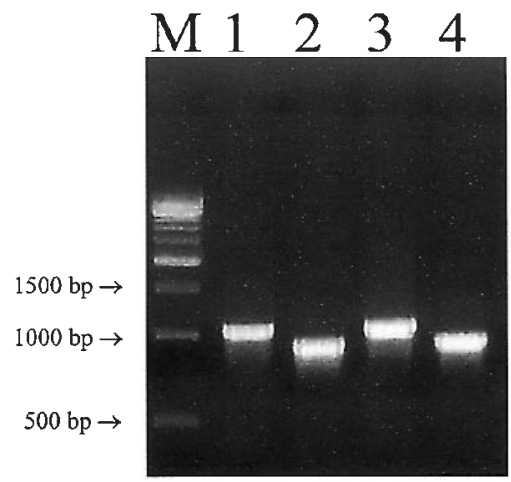

Figure 1. Ethidium bromide stained agarose gel demonstrating the PCR products using the 4 different primer combinations and P. larvae larvae DNA. Lane M: Marker; Lane 1: PCR with primers 1 and 2; Lane 2: PCR with primers 1 and 4; Lane 3: PCR with primers 3 and 2; Lane 4: PCR with primers 3 and 4 . The applied primers were given in more detail in Table II. 
Table III. List of the tested species and respective strains.

\begin{tabular}{lclc}
\hline Species & Strain & Species & Strain \\
\hline Bacillus cereus & LMG 6923 & P. apiarius & LMG 17433 \\
B. licheniformis & LMG 6933 & P. larvae pulvifaciens & LMG 15974 \\
B. megaterium & LMG 7127 & P. lautus & LMG 11157 \\
B. subtilis & LMG 7135 & P. polymyxa & LMG 13296 \\
B. thuringiensis & LMG 7138 & P. validus & LMG 9817 \\
Brevibacillus laterosporus & LMG 16000 & Melissococcus plutonius & USA* \\
Enterococcus faecalis & LMG 7937 & & Finland* \\
Paenibacillus alvei & LMG 13253 & & Tanzani** \\
& LMG 13258 & & \\
& & &
\end{tabular}

LMG: Laboratory of Microbiology Ghent, University of Ghent.

* Strains provided by B.V. Ball, UK.

In order to examine the PCR reactions with DNA extracted directly from larval remains, 141 different brood samples were tested. These brood samples were previously tested for AFB with standard isolation and identification methods combined with the examination of the symptoms. Each clinical positive brood sample resulted in an amplicon of the expected length. There was no amplicon with the negative samples nor with the subclinical samples where a few spores were found but no clinical signs were observed. The PCR was also tested on a honey sample with a high amount of $P$. larvae larvae spores, but no amplicon could be generated from that sample.

\section{DISCUSSION}

The examination of smears (Hornitzky and Wilson, 1989) offers a fast diagnosis of both AFB and EFB. However, the presence of numerous other spore-forming bacteria may lead to a non-conclusive result. Conclusive identification using the conventional laboratory diagnosis of subculturing to obtain a pure bacterial culture is hampered by the slow growth rate of $P$. larvae larvae and the presence of numerous other bacteria. Isolation and subsequently biochemical identification using standard kits as the API
50 CHB (Carpana et al., 1995) or BBL Crystal (Dobbelaere et al., 2001) can take up to two weeks. PCR provides an equally reliable but much faster diagnostic method.

Our study shows that the presented PCR is very specific for the species $P$. larvae. The only cross-reaction that we observed, was at the subspecies level with a $P$. larvae pulvifaciens strain. This bacterium is associated with powdery scale disease (Katznelson, 1950), a very rare disease of the honeybee. It came as no surprise that a PCR based on the 16S rRNA gene would not make a distinction between both subspecies. The ARDRA technique, based on the same gene, showed more than $90 \%$ similarity between strains of $P$. larvae larvae and P. larvae pulvifaciens (Heyndrickx et al., 1996). It was partly based on these results that the two species were united at the species level (Heyndrickx et al., 1996). The available sequences of the 16S rRNA gene from $P$. larvae larvae (Genbank accession No. X60619) and P. larvae pulvifaciens (Genbank accession No. X60636) are 99.44\% similar, and do not permit the construction of specific primers for one of the two subspecies alone. As $P$. larvae pulvifaciens is also regarded to be a bee pathogen, this cross-reaction can hardly be seen as a flaw of the PCR test. The high number of 
P. larvae larvae strains tested positive with PCR versus the absence of cross-reactions with various other related, non-pathogenic species highlights the diagnostic value of this technique.

In a study on European foulbrood, Govan et al. (1998) demonstrated the possibility to perform a PCR with DNA extracted directly from diseased larvae. We used a similar technique but found it unnecessary to incubate the suspension of the honeybee larvae overnight in a broth medium. No false positive or negative results were observed. One can argue that the failure to detect a few spores in a subclinical brood sample is a false negative, but in fact the brood was apparently healthy and could as such not be labelled AFB positive, as there were no clinical signs of the disease. The failure to detect the presence of a few spores by the PCR technique is probably due to the fact that the method used for DNA isolation is insufficient to isolate DNA directly from spores. The test with the strongly positive honey sample supports this hypothesis. It is most likely that in honey only the spore form of the bacterium will be present, as the vegetative form is unable to survive in honey (Hornitzky, 1998). Although it is possible to extract DNA from spores for PCR with intensive microwave radiation (Vaid and Bishop, 1998), we did not apply this technique as the necessary equipment was not available to us. Honeybee larvae killed by $P$. larvae larvae contain a large amount of spores, but also some vegetative cells of the bacterium, and these allow easy DNA isolation and subsequent PCR detection. Using the primers described for Melissococcus plutonius (Govan et al., 1998), the same PCR-mix and PCR-cycle as described in this article can be used to diagnose EFB, hence allowing a simultaneous diagnosis of both diseases with the same DNA extraction from diseased larvae. The presented diagnostic method for $P$. larvae gives a result in only 4 hours. This means a substantial improvement over the traditional methods.
And finally, this PCR technique offers an alternative for the fast identification of P. larvae colonies as demonstrated by Govan et al. (1999). It can be used to allow identification of the presence of $P$. larvae spores in honey samples or subclinical brood samples - not detected with the direct sampling technique - after culturing on a growth medium without the need for subculturing to obtain a pure culture.

\section{ACKNOWLEDGEMENTS}

This research was supported by funds from the Ministry of Small Enterprises, Traders and Agriculture, DG6 (S-5886) and by a grant of the Flemish beekeepers federation (Koninklijke Vlaamse Imkersbond).

Résumé - Mise au point d'une méthode de diagnostic rapide et fiable de la loque américaine (Paenibacillus larvae subsp. larvae) à l'aide de la PCR basée sur le gène $\mathbf{1 6 S}$ de l'ARNr. Paenibacillus larvae larvae est une bactérie difficile à croissance lente qui est à l'origine de la loque américaine (AFB), maladie essentielle des abeilles. Son isolement et son identification probable peuvent être difficile et prendre du temps. C'est pourquoi nous nous sommes attachés dans cette étude à mettre au point et évaluer une diagnose rapide de l'AFB par la PCR (réaction en chaîne de la polymérase). De nouvelles amorces de PCR ont été mises au point d'après l'alignement de plusieurs séquences du gène $16 \mathrm{~S}$ de l'ARNr (Tab. I) de diverses bactéries apparentées avec la séquence du même gène de $P$. l. larvae ( ${ }^{\circ}$ X60619 de la Genbank, http://www.ncbi. nlm.nih.gov/Genbank/). L'ADN a été isolé au moyen d'un kit d'isolement d'ADN Puregene ou d'une méthode simple comprenant chauffage et centrifugation. Pour échantillonner directement le couvain, une suspension de restes larvaires a été faite dans $1 \mathrm{~mL}$ d' $\mathrm{H}_{2} \mathrm{O}$ et diluée 10 fois avant d'extraire l'ADN par la méthode simple. On a trouvé deux nouvelles amorces et, avec les 
deux amorces précédemment décrites (Govan et al., 1999), nous disposions de quatre combinaisons d'amorces possibles pour la PCR (Tab. II). Dans les conditions de la PCR décrites, les quatre combinaisons d'amorces ont donné le produit de PCR attendu (Fig. 1). Des réactions croisées ont été testées chez un grand nombre d'espèces proches ou d'espèces que l'on trouve dans la ruche (Tab. III). La PCR n'a donné des produits d'amplification qu'avec $P$. l. pulvifaciens. Ils avaient la même longueur que ceux générés avec $P$. $l$. larvae. Ce n'est pas surprenant puisque les deux bactéries appartiennent à la même espèce. En outre la technique ARDRA, basée sur le même gène, a montré plus de $90 \%$ de similitude entre les deux espèces (Heyndrickx et al., 1996) et n'a pu séparer clairement les deux bactéries. Pour tester la possibilité d'une PCR avec l'ADN extrait directement des larves malades, 141 échantillons de couvain, sur lesquels on avait recherché auparavant l'AFB, ont été testés. Un produit d'amplification de PCR a été généré avec chaque échantillon atteint d'AFB ; aucun n'a été généré avec les échantillons sains. Les échantillons qui avaient quelques spores mais ne présentaient pas de signes cliniques n'ont pas donné non plus de produits d'amplification. Ceci est probablement dû au fait que la méthode utilisée pour isoler l'ADN ne peut pas extraire l'ADN des spores. Cette hypothèse est confirmée par le fait qu'aucun produit d'amplification n'a été généré directement à partir d'échantillons de miel contenant $P$. l. larvae. Il est très vraisemblable que seules les spores, et non les cellules végétatives, sont présentes dans le miel en raison du caractère antibactérien de celui-ci. Les restes de larves tuées par l'AFB contiennent elles aussi un grand nombre de spores, mais également quelques cellules végétatives de la bactérie et ces dernières permettent l'identification par la PCR. Cette diagnose s'est montrée fiable et rapide et fournit une alternative précieuse aux diagnoses plus classiques basées sur l'isolation et l'identification biochimique de $P$. larvae. loque américaine / diagnose / PCR / 16S ARNr / Paenibacillus larvae larvae

Zusammenfassung - Entwicklung einer schnellen und verlässlichen diagnostischen Methode zur Bestimmung der Amerikanischen Faulbrut (Paenibacillus larvae subsp. larvae) mit einer auf dem 16S rRNA Gen basierenden PCR. Paenibacillus larvae larvae ist ein anspruchsvolles und langsam wachsendes Bakterium und eine erste Isolierung und eine vorläufige Identifizierung kann schwierig und zeitaufwendig sein. Deshalb wird in dieser Arbeit angestrebt, eine schnelle Diagnose von AFB (Amerikanischer Faulbrut) mit der PCR (Polymerase-Kettenreaktion) Methode zu entwickeln und ihre Genauigkeit zu bestimmen. Neue PCR Primer wurden entwickelt, die auf einem Strang aus mehreren Sequenzen des $16 \mathrm{~S}$ rRNA Gens von P. larvae larvae (erhältlich über die Genbank Nummer X60619) basieren. Sie wurden mit den von Govan et al. (1999) beschriebenen Sequenzen verglichen (Tab. I). Die DNA wurde mit einem „Puregene DNA Isolations Kit“ oder mit der einfachen Methode über Erhitzen und Zentrifugation isoliert. Für die Probensammlung wurden larvale Überreste in $1 \mathrm{~mL}$ Wasser aufgeschwemmt und auf $10 \mathrm{~mL}$ verdünnt, bevor die DNA durch Erhitzen und Zentrifugation extrahiert wurde. Zwei neue Primer wurden gefunden und zusammen mit den 2 bereits beschriebenen (Govan et al., 1999) hatten wir 4 mögliche Primer Kombinationen für die PCR (Tab. II). Unter den beschriebenen PCR Bedingungen ergaben alle 4 Primer Kombinationen die erwarteten PCR Produkte (Abb. 1). Eine gro $\beta e$ Anzahl verwandter Arten und Arten aus dem Bienenvolk (Tab. III) wurde auf Kreuzreaktion getestet. Nur mit $P$. larvae pulvifaciens erzeugte die PCR Amplifikate. Diese Amplifikate hatten die gleiche Länge wie die von P. larvae larvae. Das war nicht unerwartet, denn beide Bakterien gehören zur gleichen Art. Außerdem ergab die ARDRA Technik, die auf dem gleichen Gen beruht, 
eine Ähnlichkeit von mehr als $90 \%$ (Heyndrickx et al., 1996) und wies keinen deutlichen Unterschied zwischen den beiden Bakterien auf.

Um die Möglichkeit einer PCR mit DNA zu testen, die direkt aus den befallenen Larven extrahiert wird, wurden 141 verschiedene Brutproben getestet, die zuvor auf AFB untersucht waren. Eine PCR Amplifikation wurde mit jeder AFB positiven Probe aber bei keiner negativen Probe erzeugt. Proben mit wenig Sporen und ohne klinische Symptome ergaben ebenfalls keine Amplifikation. Das liegt wahrscheinlich daran, dass die hier benutzte DNA Isolation nicht ausreichend DNA aus den Sporen extrahiert. Diese Annahme wird dadurch gestützt, dass keine Amplifikate aus Honigen erzeugt werden konnten, die $P$. larve larvae enthielten. Wahrscheinlich enthält der Honig wegen seiner antibakteriellen Eigenschaften nur Sporen und keine vegetativen Zellen. Überreste von Larven, die durch AFB abgetötet werden, enthalten ebenfalls große Mengen von Sporen, aber auch einige vegetative Bakterienzellen und letztere ermöglichen die Identifikation durch PCR. Die Diagnose erwies sich als zuverlässig und schnell und bildet eine Alternative zu den mehr klassischen Diagnosen, die auf einer Isolation und biochemischen Indentifikation der P. larvae larvae beruhen.

\section{Amerikanische Faulbrut / Diagnose / Paenibacillus larvae larvae / PCR / 16S rRNA Gen}

\section{REFERENCES}

Bailey L., Ball B.V. (1991) American foulbrood, in Bailey L., Ball B.V. (Eds.), Honey bee pathology, Academic Press, London, pp. 36-41.

Carpana E., Marocchi L., Gelmini L. (1995) Evaluation of the API 50CHB system for the identification and biochemical characterization of Bacillus larvae, Apidologie 26, 11-16.
Dobbelaere W., de Graaf D.C., Peeters J.E., Jacobs F.J. (2001) Comparison of two commercial kits for biochemical characterization of Paenibacillus larvae larvae in the diagnosis of AFB, J. Apic. Res., in press.

Gilliam M. (1997) Identification and roles of non-pathogenic microflora associated with honey bees, FEMS Microbiol. Lett. 155, 1-10.

Govan V.A., Brözel V., Allsopp M.H., Davison S. (1998) A PCR detection method for rapid identification of Melissococcus pluton un honeybee larvae, Appl. Environ. Microbiol. 64, 1983-1985.

Govan V.A., Allsopp M.H., Davison S. (1999) A PCR detection method for rapid identification of Paenibacillus larvae, Appl. Environ. Microbiol. 65, 2243-2245.

Heyndrickx M., Vandemeulebroecke K., Hoste B., Janssen P., Kersters K., De Vos P., Logan N.A., Ali N., Berkeley R.C.W. (1996) Reclassification of Paenibacillus (formerly Bacillus) pulfivaciens (Nakamura 1984) Ash et al. 1994, a later subjective synonym of Paenibacillus (formerly Bacillus) larvae (White 1906) Ash et al. 1994 as a subspecies of $P$. larvae, with emended descriptions of $P$. larvae as $P$. larvae subsp. larvae and $P$. larvae subsp. pulvifaciens, Int. J. Sys. Bact. 46, 270-279.

Hornitzky M.A.Z. (1998) The pathogenicity of Paenibacillus larvae subsp. larvae spores and vegetative cells to honey bee (Apis mellifera) colonies and their susceptibility to royal jelly, J. Apic. Res. 37, 267-271

Hornitzky M.A.Z., Wilson S.C. (1989) A system for the diagnosis of the major bacterial brood diseases of honeybees, J. Apic Res. 28, 191-195.

Katznelson H. (1950) Bacillus pulvifaciens (n.sp.), an organism associated with powdery scale of honeybee larvae, J. Bacteriol. 59, 153-155.

Ratnieks F.L.W., Visscher P.K., Vetter R. (1995) Treating American foulbrood using gamma radiation: a case history, Am. Bee J. 135, 557-561.

Snowdon J.A., Cliver D.O. (1996) Microorganisms in honey, Int. J. Food Microbiol. 31, 1-26.

Vaid A., Bishop A.H. (1998) The destruction by microwave radiation of bacterial endospores and amplification of the released DNA, J. Appl. Microbiol. 85, 115-122.

Vaneechoutte M., Van Eldere J. (1997) The possibilities and limitations of nucleic acid amplification technology in diagnostic microbiology, J. Med. Microbiol. 46, 188-194.

Whelen A.C., Persing D.H. (1996) The role of nucleic acid amplification and detection in the clinical microbiology laboratory, Annu. Rev. Microbiol. 50, 349-373. 